\title{
OPEM
}

www.opem.org

Oriental Pharmacy and Experimental Medicine 2008 8(3), 243-251

DOI 10.3742/OPEM.2008.8.3.243

\section{Anti-inflammatory and anti-noceceptive action of the crude extracts of Costus specious on rodents}

\author{
Md. Ashraful Alam ${ }^{1 *}$, Nusrat Subhan $^{2}$, Md. Abdul Awal ${ }^{3}$, Md. Shohidul Alam ${ }^{4}$ and Kazi Akramudaulla ${ }^{2}$ \\ ${ }^{1}$ Department of Pharmacy, Stamford University, Bangladesh; ${ }^{2}$ Pharmacy Discipline, Khulna University; \\ ${ }^{3}$ Department of Pharmacology, Bangladesh Agricultural University; ${ }^{4}$ Department of Agricultural Chemistry, \\ Bangladesh Agricultural University, Bangladesh
}

Received for publication March 14, 2007; accepted November 05, 2007

\begin{abstract}
SUMMARY
The effect of alcoholic extracts of Costus specious (Family: Zingiberaceae) was evaluated in experimental models of pain and inflammation. Oral administration of 100, 200 and $300 \mathrm{mg} / \mathrm{kg}$ of C. specious extracts were used for the above study. Crude extracts of C. specious ( $300 \mathrm{mg} / \mathrm{kg}$ dose) showed maximum time needed for the response against thermal stimuli $(7.242 \pm 0.532 \mathrm{~s})$ which is comparable to diclofenac sodium $(8.471 \pm 0.257 \mathrm{~s})$ in the hot plate test. The MPH (Maximum Possible Analgesia) has been found to be 14.285 for $300 \mathrm{mg} / \mathrm{kg}$ dose of the crude extract while the $\mathrm{MPH}$ for diclofenac was 15.857 after $60 \mathrm{~min}$ of administration in the hot tail-flick method. The crude extract at 300 and $200 \mathrm{mg} / \mathrm{kg}$ doses showed significant reduction in acetic acid induced writhings in mice with a maximum effect of $59.661 \%$ reduction at $300 \mathrm{mg} / \mathrm{kg}$ dose which is comparable to standard diclofenac sodium (73.4\%). Alcoholic extract of C. specious showed significant inhibition in serotonin and egg albumin induced hind paw oedema in rats at 100, 200 and $300 \mathrm{mg} / \mathrm{kg}$ of the crude extracts respectively (Serotonin induced edema 44.22; 53.75; 58.51\%; egg albumin induced edema $-41.317 ; 53.892 ; 59.880 \%$ inhibition after $4 \mathrm{~h}$ respectively). The antiinflammatory effects showed by the extract were comparable to that of standard indomethacin $5 \mathrm{mg} / \mathrm{kg}$ (Serotonin induced edema 77.56\%; egg albumin induced edema $77.844 \%$ inhibition after $4 \mathrm{~h}$ ). These results suggest that the extract possesses both the anti-inflammatory and analgesic activity on mice and rat model.
\end{abstract}

Key words: Costus specious; Anti-inflammatory; Anti-nociceptive; Diclofenac sodium; Indomethacin

\section{INTRODUCTION}

A scientific evaluation of herbs according to their traditional methods of use in various diseases management can incorporate into the complementary and alternative medicine system elsewhere. Costus specious is an elegant tall erect rhizomatous plant

${ }^{*}$ Correspondence: Md. Ashraful Alam, Department of Pharmacy, Stamford University, Bangladesh. E-mail: sonaliagun@yahoo.com with long spathulate broadly elliptic leaves and curved funnel shaped showy flower in terminal compact brackleate spikes, grows all over the country. (Ghani, 2003) Rhizomes contain saponins, diosgenin and tigogenin, essential oil and bisphthalate. Diosgenin and tigogenin are also present in the stem and root. (Ghani, 2003) Rhizomes and roots are also useful in catarrhal fevers, coughs, dyspepsia, worms, skin diseases and snake bite. They are also astringent, stimulant and aphrodisiac. 
(Ghani, 2003) C. speciosus contains diosgenin, and beta-glucosidase which converts a furostanol glycoside protogracillin to a spirostanol glycoside gracillin. (Indrayanto et al., 1994; Inoue et al., 1996) Saponins isolated from the crude extract of $C$. speciosus caused sterility in mice. (Tewary et al., 1973) Rhizomes of C. speciosus showed significant hypoglycemic effect when the juice was fed with simultaneous glucose load. (Mosihuzzaman et al., 1994) Supplementation of the diet with bitter yam steroidal sapogenin extract or commercial diosgenin did not significantly alter ATP citrate lyase and pyruvate kinase activities but significantly increased glucose-6-phosphate dehydrogenase activity and reduced $\mathrm{Na}^{[+]}-\mathrm{K}^{[+]}$-ATPase activity in the liver compared to diabetic rats. (Mcanuff et al., 2005a,b) The methanolic leaf extract of Costus afer showed cytotoxicity in brian shrimp lethal assay, mild anaesthetic action, induced expulsion of whole fetuses enveloped within the placental membrane at the 3rd trimester of pregnancy and markedly decrease the blood glucose level. (Anaga et al., 2004) Diosgenin dose-dependently attenuated subacute intestinal inflammation and normalized bile secretion in rat model. (Yamada et al., 1997; Matsuda et al., 2003).

It is desirable to find the pharmacological basis for these acclaimed folkloric uses of the crude extract of $C$. specious. The present study therefore investigates some of the pharmacological actions of crude extracts of $C$. specious on pain and inflammation.

\section{MATERIALS AND METHODS}

\section{Plant material}

The plant aerial parts and rhizomes of $C$. specious were collected from the Bangladesh Agricultural University Campus in December 2005 and identified by the experts of the Botanical Garden, Bangladesh Agricultural University and a voucher specimen (BAU-DP-02) was preserved in the Department of Pharmacology, Bangladesh Agricultural University.

\section{Preparation of ethanol extracts}

Dry powdered aerial parts of C. specious (400 g) were extracted with $95 \%$ of ethanol in a Soxhlet apparatus at an elevated temperature. The extract was concentrated by evaporation under reduced pressure at $40^{\circ} \mathrm{C}$ using Buchi rotary evaporator to have gummy concentrate of greenish colour extract (yield appx. 5.6\%).

\section{Phytochemical screening}

The freshly prepared extract of C. specious was qualitatively tested for the presence of chemical constituents. These were identified by characteristic color changes using standard procedures (Trease and Evans, 1983).

\section{Test samples and standards}

Suspension of C. specious crude extracts was prepared in tween $80(1 \%)$ using distilled water. The dose was selected arbitrarily considering the folkloric use of the plant parts. Diclofenac sodium $(100 \mathrm{mg} / \mathrm{kg})$ and indomethacin $(5 \mathrm{mg} / \mathrm{kg})$ were used as standards. Gastric administration of drugs was accomplished via oral gavages.

\section{Animals}

Wister rats (200 - $250 \mathrm{~g})$ and albino mice (20 - $25 \mathrm{~g})$ of either sex were used in this investigation. Wister rats and Swiss albino mice were obtained from the Animal house of the International Centre for Diarrhoeal Disease and Research, Bangladesh (ICDDR, B). Animals were maintained under standard environmental conditions and had free access to feed and water ad libitum. Experiments on animals were performed based on animal research ethical guidelines of the Institutional Animal Research Ethics Committee. Albino mice ( $n=7$, per group) were used for anti-nociceptive activity and Wister rats ( $n=5$, per group) were used for antiinflammatory screening and divided into five different groups. First group served as control animals they were treated with $1 \%$ tween 80 . Second group of animals were treated with standard 
drugs. The standard drugs diclofenac sodium 100 $\mathrm{mg} / \mathrm{kg}$ (anti-nociceptive drug) or indomethacin $5 \mathrm{mg} /$ $\mathrm{kg}$ body weight (anti-inflammatory drug) were used. The next three groups of animals were treated with the alcoholic crude extract at three different doses (100, 200 and $300 \mathrm{mg} / \mathrm{kg}$ ).

\section{Anti-nociceptive activity Hot plate test}

Albino mice were placed in aluminum hot plate kept at a temperature of $55 \pm 0.5^{\circ} \mathrm{C}$ for a maximum time of $10 \mathrm{~s}$ (Franzotti et al., 2000). Reaction time was recorded when animals licked their fore, hind paws and jumped at before and at 15, 30 and 45 min followed by oral administration of crude extract (100, 200 and $300 \mathrm{mg} / \mathrm{kg})$. Diclofenac sodium $100 \mathrm{mg} / \mathrm{kg}$ was used as a reference drug.

\section{Tail immersion/ hot tail-flick}

Mice were treated with $1 \%$ aqueous tween 80 (10 $\mathrm{ml} / \mathrm{kg})$, Diclofenac sodium $(100 \mathrm{mg} / \mathrm{kg})$ and three doses of the crude extracts $(100,200$ and $300 \mathrm{mg} /$ $\mathrm{kg})$. Antinociceptive effect of the test substances was determined by the hot tail-flick method described by Sewell and Spencer (1976). One to two centimeter of the tail of mice was immersed in warm water kept constant at $50^{\circ} \mathrm{C}$. The reaction time was the time taken by the mice to deflect their tails. The first reading is discarded and the reaction time was taken as a mean of the next two readings. The latent period of the tail-flick response was taken as the index of antinociception and was determined before and at 0,30 and $60 \mathrm{~min}$ after the administration of drugs. The maximum reaction time was fixed at $20 \mathrm{~s}$. The maximum possible analgesia (MPA) was calculated as:

$\mathrm{MPA}=\frac{\text { Test reaction time }- \text { Saline reaction time }}{20-\text { Saline reaction time }}$

\section{Acetic acid-Induced writhing test}

Antinociceptive response of $C$. specious extracts $(100,200$ and $300 \mathrm{mg} / \mathrm{kg}$ ) was assessed by counting number of writhes (constriction of abdomen, turning of trunk and extension of hind legs) induced by $1 \%$ acetic acid solution (1: $100 \mathrm{ml}$ ) in mice (Koster et al., 1959). Number of writhes per animal was counted during $30 \mathrm{~min}$ test period, beginning $3 \mathrm{~min}$ after the injection of acetic acid. Diclofenac sodium 100 $\mathrm{mg} / \mathrm{kg}$ b.wt was used as a reference drug.

\section{Anti-inflammatory activity Serotonin induced rat paw oedema}

The paw oedema was induced in the right hind paw by sub planter injection of $0.05 \mathrm{ml}$ of $1 \%$ freshly prepared solution of serotonin. (Mukherjee et al., 1997; Ahamed et al., 2005) The volume of injected paws and contra-lateral paws were measured at 1, 2, 3 and $4 \mathrm{~h}$ intervals using plethysmometer. Crude extracts of C. specious (100, 200 and $300 \mathrm{mg} / \mathrm{kg}$ ) was administered to three groups of animal and remaining groups of animals received $1 \%$ tween- 80 (Control $10 \mathrm{ml} / \mathrm{kg}$ ) and indomethacin $5 \mathrm{mg} / \mathrm{kg}$ (Standard) respectively for assessing comparative pharmacological significance.

\section{Egg albumin-induced paw edema in rats}

Egg albumin-induced rat paw edema was performed according to the method of Winter et al. (1962), Okoli and Akah (2000). Four groups of male and female Wister rats were pretreated as follows, group 1, 10\% propylene glycol; group 3, 4 and 5, 100,200 and $300 \mathrm{mg} / \mathrm{kg}$, p.o. of crude extracts and group 2 with indomethacine ( $5 \mathrm{mg} / \mathrm{kg}$, i.p.). After $30 \mathrm{~min}$, each group was injected with $0.5 \mathrm{ml}$ raw egg albumin sub-plantar to the left hind-paw. Edema was assessed in terms of volume of distilled water displaced by the paw before and at 1, 2, 3 and $4 \mathrm{~h}$ after induction of inflammation. (Hess and Milonig, 1972; Okokon et. al., 2006).

The level of inhibition of edema was calculated for each extract using the relation (Perez, 1986).

Inhibition $(\%)=100(1-(a / b))$

Where a mean paw volume of treated animals after egg albumin injection; $b$ mean paw volume of control animals after egg albumin injection. 


\section{RESULTS}

\section{Phytochemical screening}

The freshly prepared extract of $C$. specious showed a wide range of compound such as reducing sugar, steroids, flavonoids, tannins and saponins which are summarized at Table 1.

\section{Hot plate test}

Three doses of extracts of $C$. specious increased the reaction time in a dose-dependent manner to the thermal stimulus which was summarized in Table 2. The highest nociceptive inhibition of thermal stimulus was exhibited at a higher dose $300 \mathrm{mg} / \mathrm{kg}$ of crude extract which has maximum time needed for the response against thermal stimuli (7.242 \pm $0.532 \mathrm{~s}$ ) which is comparable to diclofenac sodium $(8.471 \pm 0.257 \mathrm{~s})$ and found statistically significant.

\section{Tail immersion/ hot tail-flick}

Table 3 summarizes the results of the Tail immersion/hot tail-flick test results. Three doses of

Table 1. Qualitative chemical analysis of the extract of C. specious

\begin{tabular}{lccc}
\hline Constituents & Name of test & Observation & Inference \\
\hline Alkaloids & Mayer's test & cream precipitate not found & absent (-ve) \\
Reducing suger & Fehlings solution & brick-red precipitate & present (+ve) \\
Steroids & Salkowaski's test & Red colour is developed at chloroform layer & present (+ve) \\
Flavonoids & Ammonium test & Yellow colouration & present (+ve) \\
Saponin & Frothing test & persistent foam & present (+ve) \\
Tannins & Ferric chloride test & dark green colour & present (+ve) \\
\hline
\end{tabular}

Table 2. Effect of C. specious ethanolic extracts on hot plate test in mice

\begin{tabular}{lccccc}
\hline \multirow{2}{*}{ Treatment } & \multirow{2}{*}{$\begin{array}{c}\text { Dose } \\
\text { (mg/kg, p.o.) }\end{array}$} & $\begin{array}{c}\text { 0 min } \\
\text { (Latency) }\end{array}$ & $15 \mathrm{~min}$ & $30 \mathrm{~min}$ & \multirow{2}{*}{$45 \mathrm{~min}$} \\
\hline Control (1\% aq. tween 80) & $10 \mathrm{ml} / \mathrm{kg}$ & $1.842 \pm 0.297$ & $2.557 \pm 0.148$ & $2.985 \pm 0.316$ & $2.971 \pm 0.311$ \\
\hline Diclofenac-Na & 100 & $1.814 \pm 0.181$ & $6.157 \pm 0.474^{*}$ & $6.857 \pm 0.302^{*}$ & $8.471 \pm 0.257^{*}$ \\
\hline & 100 & $2.114 \pm 0.258$ & $3.885 \pm 0.343^{*}$ & $4.171 \pm 0.350^{*}$ & $4.814 \pm 0.337^{*}$ \\
C. specious extract & 200 & $1.985 \pm 0.123$ & $4.814 \pm 0.208^{*}$ & $4.757 \pm 0.176^{*}$ & $5.871 \pm 0.372^{*}$ \\
& 300 & $2.085 \pm 0.184$ & $5.514 \pm 0.529^{*}$ & $6.128 \pm 0.243^{*}$ & $7.242 \pm 0.532^{*}$ \\
\hline
\end{tabular}

${ }^{\prime} P<0.05$ vs. control, Student's $t$-test; values are mean \pm S.E. $(N=7)$.

Table 3. Effect of C. specious ethanolic extracts on hot tail -flick test in mice

\begin{tabular}{|c|c|c|c|c|}
\hline \multirow{2}{*}{ Treatment } & \multirow{2}{*}{$\begin{array}{c}\text { Dose } \\
\text { (mg/kg, p.o.) }\end{array}$} & \multicolumn{3}{|c|}{ Response Time (s) } \\
\hline & & $0 \mathrm{~min}$ & $30 \mathrm{~min}$ & $60 \mathrm{~min}$ \\
\hline Control (1\% aq. tween 80$)$ & $10 \mathrm{ml} / \mathrm{kg}$ & $2.571 \pm 0.398$ & $3.571 \pm 0.519$ & $2.857 \pm 0.281$ \\
\hline Diclofenac-Na & 100 & $\begin{array}{l}4.285 \pm 0.308 \\
\text { (MPA 1.585) }\end{array}$ & $\begin{array}{r}14.77 \pm 0.579 \\
(\text { MPA } 10.95)\end{array}$ & $\begin{array}{r}18.857 \pm 0.367 \\
(\mathrm{MPA} 15.857)\end{array}$ \\
\hline \multirow{3}{*}{ C. specious extract } & 100 & $\begin{array}{l}2.428 \pm 0.321 \\
(\text { MPA } 0.271)\end{array}$ & $\begin{array}{c}12.714 \pm 0.840 \\
(\text { MPA } 8.964)\end{array}$ & $\begin{array}{c}14.285 \pm 0.563^{*} \\
(\mathrm{MPA} 11.28)\end{array}$ \\
\hline & 200 & $\begin{array}{l}4.285 \pm 0.454 \\
(\text { MPA } 1.585)\end{array}$ & $\begin{array}{c}13.571 \pm 0.845^{*} \\
\text { (MPA 9.821) }\end{array}$ & $\begin{array}{l}15.28 \pm 0.610 \\
(\mathrm{MPA} 12.285)\end{array}$ \\
\hline & 300 & $\begin{array}{r}4.428 \pm 0.398 \\
\text { (MPA 1.728) }\end{array}$ & $\begin{array}{r}14.285 \pm 1.147 \\
(\text { MPA } 10.535)\end{array}$ & $\begin{array}{r}17.285 \pm 0.806 \\
\text { (MPA } 14.285)\end{array}$ \\
\hline
\end{tabular}

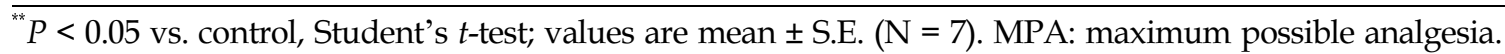


Table 4. Effect of $C$. specious ethanolic extract on acetic acid induced writhing in mice

\begin{tabular}{lccccc}
\hline Treatment & $\begin{array}{c}\text { Dose }^{*} \\
(\mathrm{mg} / \mathrm{kg})\end{array}$ & $\begin{array}{c}\text { Route of } \\
\text { administration }\end{array}$ & Writhings & \% of writhing & $\begin{array}{c}\text { \% inhibition of } \\
\text { writhing }\end{array}$ \\
\hline Control (1\% aq. tween 80$)$ & $10 \mathrm{ml} / \mathrm{kg}$ & p.o. & $33.28 \pm 1.019$ & $100 \pm 3.06$ & - \\
\hline Diclofenac-Na & 100 & i.p. & $8.857 \pm 0.863^{\mathrm{a}}$ & $26.60 \pm 2.59$ & $73.4 \%$ \\
\hline \multirow{3}{*}{ C. specious extract } & 100 & p.o. & $26.714 \pm 0.872^{\mathrm{a}}$ & $80.25 \pm 2.62$ & $19.75 \%$ \\
& 200 & p.o. & $19.428 \pm 0.877^{\mathrm{a}}$ & $58.36 \pm 2.63$ & $41.64 \%$ \\
& 300 & p.o. & $13.428 \pm 0.967^{\mathrm{a}}$ & $40.34 \pm 2.90$ & $59.66 \%$ \\
\hline
\end{tabular}

${ }^{* *}$ Administered $45 \mathrm{~min}$ before $0.7 \%$ acetic acid administration $\left(10 \mathrm{ml} / \mathrm{kg}\right.$, i.p.); ${ }^{*}$ Counted for $15 \mathrm{~min}$, starting $5 \mathrm{~min}$ after acetic acid administration; ${ }^{\mathrm{a}} P<0.05$ vs. control, Student's $t$-test; values are mean \pm S.E. $(N=7)$.

Table 5. Effect of C. specious ethanolic extracts on serotonin induced oedema test in rat

\begin{tabular}{|c|c|c|c|c|c|}
\hline \multirow{2}{*}{ Treatment } & \multirow{2}{*}{$\begin{array}{c}\text { Dose } \\
\text { (mg/kg, p.o.) }\end{array}$} & \multicolumn{4}{|c|}{ Edema volume $(\mu \mathrm{l})$} \\
\hline & & $1 \mathrm{~h}$ & $2 \mathrm{~h}$ & $3 \mathrm{~h}$ & $4 \mathrm{~h}$ \\
\hline Control (1\% aq. tween 80$)$ & $10 \mathrm{ml} / \mathrm{kg}$ & $14.8 \pm 0.418$ & $17.0 \pm 0.79$ & $24.2 \pm 0.741$ & $29.4 \pm 1.44$ \\
\hline Indomethacin & 5 & $\begin{array}{l}5.4 \pm 0.57^{*} \\
(63.52)\end{array}$ & $\begin{array}{c}5.6 \pm 0.57^{3} \\
(67.06)\end{array}$ & $\begin{array}{c}7.8 \pm 0.418^{8 *} \\
(67.77)\end{array}$ & $\begin{array}{c}6.6 \pm 0.57^{* x} \\
(77.56)\end{array}$ \\
\hline \multirow{3}{*}{ C. specious extract } & 100 & $\begin{array}{c}6.8 \pm 0.651 \\
(54.06)\end{array}$ & $\begin{array}{c}16.8 \pm 0.961 \\
(1.18)\end{array}$ & $\begin{array}{c}17.6 \pm 0.57 \\
(27.28)\end{array}$ & $\begin{array}{c}16.4 \pm 1.15 \\
(44.22)\end{array}$ \\
\hline & 200 & $\begin{array}{c}6.4 \pm 0.836 \\
(56.76)\end{array}$ & $\begin{array}{c}13.0 \pm 0.790 \\
(23.53)\end{array}$ & $\begin{array}{c}15.4 \pm 0.57^{* * x} \\
(36.37)\end{array}$ & $\begin{array}{c}13.6 \pm 0.57^{*} \\
(53.75)\end{array}$ \\
\hline & 300 & $\begin{array}{c}5.8 \pm 0.821 \\
(60.82)\end{array}$ & $\begin{array}{c}8.2 \pm 0.961 \\
(51.77)\end{array}$ & $\begin{array}{c}13.2 \pm 0.6511^{* x} \\
(45.46)\end{array}$ & $\begin{array}{l}12.2 \pm 1.11 \\
(58.51)\end{array}$ \\
\hline
\end{tabular}

${ }^{{ }^{*}} P<0.05$ vs. control, Student's $t$-test; values are mean \pm S.E. $(\mathrm{N}=5)$. Parenthesis signify the $\%$ inhibition of oedema volume.

extracts of C. specious increased the reaction time in a dose-dependent manner to the thermal stimulus as seen in the hot plate test. The highest nociceptive inhibition of thermal stimulus was exhibited at a higher dose $300 \mathrm{mg} / \mathrm{kg}$ of crude extract $(17.285 \pm$ $0.806 \mathrm{~s})$, which is comparable to diclofenac sodium $(18.857 \pm 0.367 \mathrm{~s})$ and was statistically significant.

\section{Acetic acid-induced writhing test}

Dose dependent antinoceceptive effect was also noted with the extract at the tested dose levels in acetic acid-induced writhing test (Table 4). Maximum percentage of inhibition of writhing response exhibited $59.66 \%$ by the extract at $300 \mathrm{mg} / \mathrm{kg}$ while the same at 200 and $100 \mathrm{mg} / \mathrm{kg}$ showed 41.64 and $19.75 \%$ reduction in acetic acid induced writhing response respectively. It was very much comparable to that of standard diclofenac sodium $(100 \mathrm{mg} / \mathrm{kg})$ caused $73.4 \%$ pain inhibition.

\section{Serotonin induced rat paw oedema}

Serotonin induced rat paw oedema test results were reported in Table 5. It was observed that crude extracts of $C$. specious exerted a significant edema reduction from the first hour and remained along the time. Administration of $C$. specious at different doses produced significant inhibition $(P<$ 0.05 ) of oedema at the end of $4 \mathrm{~h}$ with serotonin administration. However higher dose 200 and 300 $\mathrm{mg} / \mathrm{kg}$ of C. specious extracts exhibited maximum inhibition of paw edema ( 53.75 and $58.51 \%$ ) respectively and this effect was comparable to that of standard drug indomethacin $(77.56 \%)$ treated group.

\section{Egg albumin induced edema test}

Effect of the extracts and reference drug on paw edema induced by egg albumin has been shown in Table 6. Paw edema in rats reached its peak at $3 \mathrm{~h}$ after Egg albumin administration. Administration 
Table 6. Effect of C. specious ethanolic extracts on egg albumin induced edema test in rat

\begin{tabular}{|c|c|c|c|c|c|}
\hline \multirow{2}{*}{ Treatment } & \multirow{2}{*}{$\begin{array}{c}\text { Dose } \\
(\mathrm{mg} / \mathrm{kg}, \text { p.o. })\end{array}$} & \multicolumn{4}{|c|}{ Edema volume $(\mu \mathrm{l})$} \\
\hline & & $1 \mathrm{~h}$ & $2 \mathrm{~h}$ & $3 \mathrm{~h}$ & $4 \mathrm{~h}$ \\
\hline Control (1\% aq. tween 80$)$ & $10 \mathrm{ml} / \mathrm{kg}$ & $15.6 \pm 0.758$ & $18.4 \pm 0.908$ & $25.2 \pm 1.387$ & $33.4 \pm 1.20$ \\
\hline Indomethacin & 5 & $\begin{array}{c}8.2 \pm 0.418^{* *} \\
(47.435)\end{array}$ & $\begin{array}{c}9.6 \pm 0.758^{* *} \\
(47.826)\end{array}$ & $\begin{array}{c}8.2 \pm 0.9611^{* *} \\
(67.460)\end{array}$ & $\begin{array}{c}7.4 \pm 0.57^{\text {s* }} \\
(77.844)\end{array}$ \\
\hline \multirow{3}{*}{ C. specious extract } & 100 & $\begin{array}{c}9.8 \pm 0.821^{* *} \\
(37.179)\end{array}$ & $\begin{array}{c}15.2 \pm 1.244^{* *} \\
(17.391)\end{array}$ & $\begin{array}{c}17.4 \pm 0.758^{\text {** }} \\
(30.952)\end{array}$ & $\begin{array}{c}19.6 \pm 0.90^{* \pi *} \\
(41.317)\end{array}$ \\
\hline & 200 & $\begin{array}{c}8.6 \pm 1.09^{\text {** }} \\
(44.871)\end{array}$ & $\begin{array}{c}13.2 \pm 0.741^{\text {* }} \\
(28.260)\end{array}$ & $\begin{array}{c}16.2 \pm 0.741^{\text {*x }} \\
(35.714)\end{array}$ & $\begin{array}{c}15.4 \pm 0.83^{\text {** }} \\
(53.892)\end{array}$ \\
\hline & 300 & $\begin{array}{c}8.4 \pm 0.97^{* \pi} \\
(46.153)\end{array}$ & $\begin{array}{c}10.2 \pm 0.821 \\
(44.565)\end{array}$ & $\begin{array}{c}13.8 \pm 0.961^{* x} \\
(45.238)\end{array}$ & $\begin{array}{c}13.4 \pm 0.758^{*} \\
(59.880)\end{array}$ \\
\hline
\end{tabular}

${ }^{* *} P<0.05$ vs. control, Student's $t$-test; values are mean \pm S.E. $(\mathrm{N}=5)$. Parenthesis signify the $\%$ inhibition of oedema volume.

of various doses of $C$. specious produced a significant inhibition of the oedema at the end of $4 \mathrm{~h}$ with egg albumin administration. Maximum percentage of inhibition of oedema exhibited by the C. specious extract at $300 \mathrm{mg} / \mathrm{kg}$ was $59.88 \%$. This effect was comparable to that standard drug indomethacin (77.84\%).

\section{DISCUSSION}

In this work, we have demonstrated the effect of ethanolic extract of C. specious (100 - $300 \mathrm{mg} / \mathrm{kg}$; p.o.) on various experimental model of analgesic and anti-inflammatory tests in mice. The methods for investigating analgesic effects of the crude ethanolic extract of $C$. specious were selected such that both centrally and peripherally mediated effects were investigated. Pain and inflammation is associated with many pathophysiology of various clinical conditions like arthritis, cancer and vascular diseases (Weitzman and Gordon, 1990; Suffness and Pezzuto, 1991; Mukherjee, 2003). A number of natural products are used in various traditional medical systems to treat relief of symptoms from pain and inflammation. The crude extracts of $C$. specious demonstrated significant anti-nociceptive activity at three different dose levels in various animal models of pain. Acetic acid-induced writhing response elucidated peripheral activity, while the hot plate tests, hot tail flick test investigated both peripheral and central activity. (D'Amour and Smith, 1941; Ghule et al., 2006) Nociceptive reaction towards thermal stimuli in hot plate test and tail immersion in hot water test using mice is a well-validated model for detection of opiate analgesic as well as several types of analgesic drugs from spinal origin (Sewell and Spencer, 1976; Owoyele et al., 2001; Adzu et al., 2003). Nociceptive pain inhibition was noticed highest in both the test at $45 \mathrm{~min}$ after administration of the extracts and the response time is increased from $2.085 \mathrm{~s}$ to $7.242 \mathrm{~s}$ in hot plate test at dose 300 $\mathrm{mg} / \mathrm{kg}$ while it was also increased from $4.428 \mathrm{~s}$ to $17.285 \mathrm{~s}$ in tail flick test at the same dose level. Other doses used in this study also increases the latent period significantly with the time being in both tests.

Acetic acid-induced writhing test has been used as a model of chemonociceptive induced pain, which increases $\mathrm{PGE}_{2}$ and $\mathrm{PGF}_{2 \alpha}$ peripherally (Collier et al., 1968). The crude ethanolic extract of C. specious showed significant reduction of abdominal contraction in mice. Local peritoneal receptors were postulated to be partly involved in the abdominal constriction (writhing) response (Koster et al., 1956; Ghule et al., 2006). The method has been associated with prostanoids in general, i.e. increased levels of $\mathrm{PGE}_{2}$ and $\mathrm{PGF}_{2 \alpha}$ in peritoneal fluids 
(Koster et al., 1956; Hendershot and Forsaith, 1959) as well as lipoxygenase products by some researchers (Ghule et al., 2006). The extract might inhibit the synthesis and/or release these endogenous substances.

Diclofenac, a non-steroidal anti-inflammatory drug, is commonly employed in the treatment and/or management of rheumatoid arthritis, osteo-arthritis and ankylosing spondylitis (Eddy and Leimback, 1953; Siraux, 1977) and for its antiinflammatory and analgesic effects (Brooks et al., 1980). Diclofenac reduces inflammation, swelling and arthritic pain by inhibiting prostaglandins synthesis and/or production (Skoutakis et al., 1988; Todd and Sorkin, 1988; Small, 1989). The drug also affects polymorphonuclear leukocytes function in vitro, thereby reducing chemotaxis, superoxide toxic radical formation, oxygen-derived free radical generation and neutral protease production (Freeman et al., 1986; Mahgoub, 2002). Diclofenac has also been reported to suppress inflammation induced by various phlogistic agents in experimental animal models (Menasse et al., 1978; Freeman et al., 1986; Al-Tuwaijri et al., 1992). In the present study, the reduction of the antinociceptive process obtained within the first hour is probably related to reduction in the release of preformed inflammatory agents, rather than to a reduced synthesis of the inflammatory mediators by inhibition of cyclooxygenases and/or lipoxygenases (and other inflammatory mediators). Thus the anti-nociceptive activity shown by crude extracts of $C$. specious in hot plate, hot tail-flick and acetic acid induced writhing test indicate that alcoholic extracts of the plant might possess centrally and peripherally mediated antinociceptive properties.

Our experimental results also revealed that the administration of crude extract of $C$. specious inhibited the edema starting from the first hour and during all phases of inflammation, which is probably inhibition of different aspects and chemical mediators of inflammation. The effects of alcoholic extract of $C$. specious in inflammation process induced by serotonin suggest that they act by affecting a time delayed system in a similar fashion to glucocorticoids (Ahamed et al., 2005; Ghule et al., 2006). Higher dose of C. specious reduced the edema volume to a considerable level $(12.2 \mu \mathrm{l}$ at $300 \mathrm{mg} / \mathrm{kg}$ ) compared to the control group animal which received no treatment $(29.4 \mu \mathrm{l})$ at 4 hour observations.

Egg albumin induced edema is another useful tool for describing the systemic inflammation and mediated by the release of histamine and prostaglandin (Okoli et al., 2005). It suppressed in a dose related manner the increase in the rat paw edema caused by egg albumin. The $\%$ inhibition of edema volume was $41.317 \%$ at $100 \mathrm{mg} / \mathrm{kg}$ dose while it was $59.88 \%$ at $300 \mathrm{mg} / \mathrm{kg}$ dose as compared to the control group animal.

Egg albumin induced edema test is well suited with the inflammatory process which is not sustained for long. (Akah et al., 1993; Adzu and Haruna, 2007) The inhibition of edema volume after administration of various doses $(100 \mathrm{mg}$ - 300 $\mathrm{mg} / \mathrm{kg}$ ) of the extract was maximal after 3hours of administration of this phlogistic agent which is as similar phenomenon as reported by Okokon et al. (2006).

The chemical analysis of the extracts showed the presence of reducing sugar, steroids, flavonoids, tannins and saponins (Table 1) as the major constituents which were previously reported (Indrayanto et al., 1994; Inoue et al., 1996). The ability of the extracts to suppress abdominal writhes, increase pain threshold latency, suppression of the serotonin and egg albumin induced inflammation confirms the analgesic and anti-inflammatory properties of the extract. These findings justify traditional use of this plant in the treatment of pain and other inflammatory conditions and validate its claim of being used for the said purpose in folklore medicine. It can be concluded that alcoholic extracts of $C$. specious possesses analgesic and antiinflammatory properties, which are probably mediated via inhibition of prostaglandin synthesis as well as central inhibitory mechanisms which 
may be of potential benefit for the management of pain and inflammatory disorders.

\section{ACKNOWLEDGEMENTS}

The authors are very thankful to the University authority of Bangladesh Agricultural University for providing necessary logistics.

\section{REFERENCES}

Adzu B, Haruna AK. (2007) Studies on the use of Zizyphus spina-christi against pain in rats and mice. Afr. J. Biotechnol. 6, 1317-1324.

Adzu B, Amos S, Kapu SD, Gamaniel KS. (2003) Antiinflammatory and anti-nociceptive effects of Sphaeranthus senegalensis. J. Ethnopharmacol. 84, 169173.

Ahamed KFHN, Kumar V, Raja S, Mukherjee K, Mukherjee PK. (2005) Anti-nociceptive and antiinflammatory activity of Araucaria bidwillii hook. Iran. J. pharmacol. Therap. 4, 105-109.

Akah PA, Okogun JI, Ekpendu TO. (1993). Antioedema and analgesic actions of Diodia scandans extracts in rats and mice. Phytother. Res. 7, 317-319.

Al-Tuwaijri AS, Mustafa AA. (1992) Verapamil enhances the inhibitory effect of diclofenac on the chemiluminescence of human polymorphonuclear leukocytes and carrageenan-induced rat's paw oedema. Int. J. Immunopharmacol. 14, 83-91.

Anaga AO, Njoku CJ, Ekejiuba ES, Esiaka MN, Asuzu IU. (2004) Investigations of the methanolic leaf extract of Costus afer. Ker for pharmacological activities in vitro and in vivo. Phytomedicine 11, 242248.

Brooks PM, Hill W, Geddes R. (1980) Diclofenac and ibuprofen in rheumatoid arthritis and osteoarthritis. Med. J. Aust. 1, 29-30.

Collier HOJ, Dinneen LC, Johnson CA, Schneider C. (1968) The abdominal constriction response and its suppression by analgesic drugs in the mouse. $\mathrm{Br}$. J. Pharmacol. 32, 295-310.

D'Amour FE, Smith DL. (1941) A method for determining loss of pain sensation. J. Pharmacol. Exp. Ther. 72, 74-79.

Eddy ND, Leimback D. (1953) Synthetic analgesics: II.
Dithyienylbutenylamines and dithyienylbutylamines. J. Pharmacol. Exp. Ther. 3, 544-547.

Franzotti EM, Santos CVF, Rodrigues, HMSL, Mourao RHV, Andrade MR, Antoniolli AR. (2000) Anti-inflammatory, analgesic activity and acute toxicity of Sida cordifolia L.(Malva-branca). J. Ethnopharmacol. 72, 273-8.

Freeman C, Johnston C, Chew C, Davis P. (1986) Effect of diclofenac sodium, tolfenamic acid and indomethacin on the production of superoxide induced by $\mathrm{N}$-formyl-methionyl-leucyl-phenylalanine in normal human polymorphonuclear leukocytes. Scand. J. Rheumatol. 15, 41-46.

Ghani A. (2003) Medicinal plants of Bangladesh with chemical constituents and uses, $2^{\text {nd }} \mathrm{ed}$. Asiatic society of Bangladesh. pp.183-184.

Ghule BV, Ghante MH, Upaganlawar AB, Yeole PG. (2006) Analgesic and Anti-Inflammatory activities of Lagenaria siceraria Stand. Fruit juice extract in rats and mice. Pharmacognosy Mag. 2, 232-236.

Hendershot LC, Forsaith J. (1959) Antagonism of the frequency of phenylquinone-induced writhing in the mouse by weak analgesics and nonanalgesics. J. Pharmacol. Exp. Ther. 125, 237-240.

Hess SM, Milonig RC. (1972) In L.H. Lepow and P.S. Ward (Eds) Inflammation, Mechanism and Control. Academic Press. New York.

Indrayanto I, Setiawan B, Cholies N. (1994) Differential diosgenin accumulation in Costus speciosus and its tissue cultures. Planta Med. 60, 483-484.

Inoue K, Shimomura K, Kobayashi S, Sankawa U, Ebizuka Y. (1996) Conversion of furostanol glycoside to spirostanol glycoside by beta-glucosidase in Costus speciosus. Phytochemistry 41, 725-727.

Koster R, Anderson M, Debber EJ. (1959) Acetic acid for analgesic screening. FASEB J. 18, 412.

Mahgoub AA. (2002) Grapefruit juice potentiates the anti-inflammatory effects of diclofenac on carrageenaninduced rat's paw oedema. Pharmacol. Res. 45, 1-4.

Matsuda H, Pongpiriyadacha Y, Morikawa T, Kishi A, Kataoka S, Yoshikawa M. (2003) Protective effects of steroid saponins from Paris polyphylla var. yunnanensis on ethanol- or indomethacin-induced gastric mucosal lesions in rats: structural requirement for activity and mode of action. Bioorg. Med. Chem. Lett. 13, 1101-1106.

Mcanuff MA, Omoruyi FO, Morrison EY, Asemota 
HN. (2005a) Changes in some liver enzymes in streptozotocin-induced diabetic rats fed sapogenin extract from bitter yam (Dioscorea polygonoides) or commercial diosgenin. West Indian Med. J. 54, 97101.

Mcanuff MA, Harding WW, Omoruyi FO, Jacobs H, Morrison EY, Asemota HN. (2005b) Hypoglycemic effects of steroidal sapogenins isolated from jamaican bitter yam, dioscorea polygonoides. Food Chem. Toxicol. 43, 1667-1672.

Menasse R, Medwall PR, Kractz T, Pericin C, Riesterer L, Sallmann A, Ziel R. (1978) Pharmacological properties of diclofenac sodium and its metabolites. Scand. J. Rheumatol. 22, 5-16.

Mosihuzzaman M, Nahar N, Ali L, Rokeya B, Khan AK, Nur E Alam M, Nandi RP. (1994) Hypoglycemic effects of three plants from eastern Himalayan belt. Diabetes Res. 26, 127-138.

Mukherjee PK, Mukherjee K, Das J, Pal M, Saha BP. (1997) Studies on the Anti-inflammatory Activity of Rhizomes of Nelumbo nucifera. Planta Med. 63, 367369.

Mukherjee PK. (2003) Exploring botanicals in Indian systems of medicine-regulatory perspectives. Clin. Res. Regul. Affair. 20, 249-264.

Okokon JE, Antia BS, Ita BN. (2006) Anti-Inflammatory and Anti-nociceptive Effects of Ethanolic Extract of Setaria megaphylla Leaves in Rodents. Afr. J. Biomed. Res. 9, 229 -233.

Okoli CO, Akah PA. (2000) A pilot evaluation of the anti-inflammatory activity of Culcasia scandens, a traditional antirheumatic agent. J. Altern. Complement Med. 6, 423-427.

Okoli CO, Akah PA, Ezugworie U. (2005) Antiinflammatory activity of extracts of root bark of securidaca longipedunculata fres (polygalaceae). Afr. J. Traditional complement. Altern. Med. 2, 54-63.

Owoyele BV, Olaleye SB, Oke JM, Elegbe RA. (2001) Anti-inflammatory and analgesic activities of leaf extracts of landolphia owariensis. Afr. J. Biomed. Res. 4, 131-133.

Perez GRM. (1996) Anti-inflammatory activity of
Ambrosia artemisiaefolia and Rheo spathacea. Phytomedicine 3, 163-167.

Sewell RDE, Spencer PSJ. (1976) Antinociceptive activity of narcotic agonist and partial agonist analgesics and other agents in the tail-immersion test in mice and rats. Neuropharmacol. 15, 23-29.

Siraux P. (1977) Diclofenac (voltaren $\circledR$ ) for the treatment of osteoarthritis: a double-blind comparison with naproxen. J. Int. Med. Res. 5, 169-174.

Skoutakis VA, Carter CA, Mickle TR, Smith VH, Arkin CR, Alissandratos J, Pretty DE. (1988) Review of diclofenac and evaluation of its place in therapy as a non-steroidal anti-inflammatory agent. Drug Intell. Clin. Pharm. 22, 805-859.

Small RE. (1989) Drug reviews: diclofenac sodium. Clin. Pharm. 8, 545-558.

Suffness M, Pezzuto JM. (1991) Assay related to cancer drug discovery. In Methods in Plant Biochemistry, Academic press: New York, p. 6-92.

Tewary PV, Chaturvedi C, Pandey VB. (1973) Antifertility activity of Costus speciosus Sm. Indian J. Pharmacol. 35, 114-115.

Todd PA, Sorkin EM. (1988) Diclofenac sodium: a reappraisal of its pharmacodynamic and pharmacokinetic properties and therapeutic efficacy. Drugs 35, 244-285.

Trease GE, Evans WC. (1983) Pharcognosy, 12th Ed. Baillieere Tindal, London.

Weitzman SA, Gordon LI. (1990) Inflammation and cancer, role of phagocyte generated oxidants in carcinogenesis. Blood 76, 655-663.

Winter CA, Risley EA, Nuss GW. (1962) Carrageenininduced edema in the hind paw of rat as an assay for anti-inflammatory drugs. Proc. Soc. Biol. Med. 11, 544-547.

Yamada T, Hoshino M, Hayakawa T, Ohhara H, Yamada $H$, Nakazawa $T$, Inagaki $T$, Iida $M$, Ogasawara T, Uchida A, Hasegawa C, Murasaki G, Miyaji M, Hirata A, Takeuchi T. (1997) Dietary diosgenin attenuates subacute intestinal inflammation associated with indomethacin in rats. Am. J. Physiol. 273, G355-364. 